\title{
Ostarine and Ligandrol Improve Muscle Tissue in an Ovariectomized Rat Model
}

\section{OPEN ACCESS}

Edited by:

Eva Terzibasi Tozzini,

University of Naples Federico II, Italy

Reviewed by:

Patrick Diel,

German Sport University

Cologne, Germany

Eija K. Laakkonen,

University of Jyväskylä, Finland

*Correspondence:

Paul Jonathan Roch pauljonathan.roch@med. uni-goettingen.de

tThese authors have contributed equally to this work

Specialty section:

This article was submitted to Endocrinology of Aging,

a section of the journal

Frontiers in Endocrinology

Received: 12 May 2020

Accepted: 17 August 2020 Published: 17 September 2020

Citation:

Roch PJ, Henkies D, Carstens JC, Krischek C, Lehmann W, Komrakova M and Sehmisch S (2020)

Ostarine and Ligandrol Improve

Muscle Tissue in an Ovariectomized Rat Model.

Front. Endocrinol. 11:556581 doi: 10.3389/fendo.2020.556581

\section{Paul Jonathan Roch ${ }^{1 *}$, Danny Henkies ${ }^{1}$, Jan Christoph Carstens ${ }^{1}$, Carsten Krischek ${ }^{2}$, Wolfgang Lehmann ${ }^{1}$, Marina Komrakova ${ }^{1 \dagger}$ and Stephan Sehmisch ${ }^{1+}$}

${ }^{1}$ Department of Trauma Surgery, Orthopaedics and Plastic Surgery, University of Göttingen, Göttingen, Germany, ${ }^{2}$ University of Veterinary Medicine Hannover, Foundation, Hannover, Germany

In postmenopausal women, hormonal decline changes muscle function and structure. The non-steroidal selective androgen receptor modulators (SARMs) Ostarine (OS) and Ligandrol (LG) have been shown to increase muscle mass and physical function while showing a relative low risk profile. Information about their effects on muscle structure and metabolism is lacking. To analyze this, two experiments were performed using ovariectomized rats as a standard model for postmenopausal conditions. In each experiment, 3-month old Sprague-Dawley rats were divided into five groups ( $n=12$ to 15). One group remained intact (Non-OVX), the other four groups were ovariectomized $(\mathrm{OVX})$ and remained untreated for eight (OS Experiment) or nine (LG Experiment) weeks. Thereafter, rats of three of the four OVX groups were treated with OS or LG (with doses of $0.04,0.4$, or $4 \mathrm{mg} / \mathrm{kg}$ body weight/day) for 5 weeks. Then, uterus, gastrocnemius, and soleus muscles were weighed, fiber size, capillary density, and enzyme activity (lactate dehydrogenase [LDH], citrate synthase [CS], and complex I) were analyzed. In the LG experiment, intramuscular fat content was determined in the quadriceps femoris muscle. All OS treatments resulted in a higher capillary density in the gastrocnemius and longissimus muscles compared with the Non-OVX and the OVX rats, whereas all LG treatments showed a higher capillary density compared with the Non-OVX group. Muscle fiber size and distribution patterns were not changed under either SARM. The CS activity was higher in the longissimus muscle under OS treatment. LG resulted in a higher activity of $\mathrm{CS}$ in the gastrocnemius and of $\mathrm{LDH}$ in the longissimus muscle. Both SARMs showed an uterotrophic effect, OS at 4 and 0,4 mg dosages, LG at 4 mg dosage. In sum, beneficial effect on muscle vascularization was observed for both SARMs with a stronger impact for OS. LG showed more effect on muscle metabolism. However, a higher muscle weight and intramuscular fat content observed after LG treatment $(4 \mathrm{mg})$ as well as an uterotrophic effect of both SARMs at higher dosages could be considered as an unfavorable side effects and might be a limitation for their application at these dosages.

Keywords: ovariectomized rats, postmenopausal osteoporosis, selective androgen receptor modulators (SARMs), ostarine, ligandrol, muscle correspondence 


\section{INTRODUCTION}

Musculoskeletal disorders account for approximately one-third of diseases and illness of the elderly in industrial nations and continue to show an upward trend (1). Consequently, the risk of falls has increased, and fractures are becoming a more common injury. Instability and injuries after falls are interdependent $(2,3)$. The primary causes for musculoskeletal disorders are sarcopenia and osteoporosis $(1,4)$. Both, sarcopenia and osteoporosis are under continuous research and definitions are in change. While osteoporosis may be described with reduced bone mass that results in decreased bone stability and increased fracture risk (5), sarcopenia is considered when low muscle strength, quality or quantity and low physical performance occur (6). In women, hormonal changes such as the decline in estrogen in the postmenopausal metabolism may support the development of both sarcopenia and osteoporosis $(5,7)$.

Hormone replacement therapy in postmenopausal women is associated with severe side effects, such as an increased risk of coronary heart disease, breast cancer, stroke, and venous thromboembolism $(8,9)$. Nevertheless, it is still the most effective treatment for postmenopausal symptoms and for carefully selected women, benefits could exceed risks $(10,11)$. Selective estrogen receptor modulators have beneficial effects on the musculoskeletal system like estrogen, they have fewer adverse events on breasts and the uterus. However, they are still associated with venous thromboembolism and stroke $(12,13)$.

Alternatively, testosterone supplementation has been shown to increase muscle strength in men and to prevent muscle atrophy in orchidectomized male mice (14-17). Although beneficial effects on sexual function, personal distress, and blood lipids were observed in postmenopausal women, administration of testosterone in women is controversial since long-term studies are lacking to prove safety (18). In men, testosterone supplementation is associated with an increased risk of respiratory, cardiac, and dermatologic side effects (19).

Selective androgen receptor modulators (SARMs) were developed to overcome the side effects and the poor oral bioavailability and pharmacokinetic profile of testosterone (20, 21). While the exact mechanism of the action of SARMs is not fully understood, the key reason for higher tissue specificity and more favorable pharmacokinetics is considered to be their resistance to aromatization or 5 - $\alpha$-reduction $(22,23)$. Ostarine (OS) (enobosarm, S-22, MK-2866, or GTx-024) and Ligandrol (LG) (LGD-4033, VK5211) are both non-steroidal SARMs. OS was been shown to increase the lean body mass and physical function in elderly men and postmenopausal women as well as reduce muscle wasting in patients with cancer (24-26). For LG,

Abbreviations: ATPase, Adenosine-triphosphatase; CS, Citrate synthase; CK, Creatine kinase; FTG, Fast-twitch glycolytic (fiber type IIb); FTO, Fasttwitch oxidative (fiber type IIa); GM, Gastrocnemius muscle; LDH, Lactate dehydrogenase; LG, Ligandrol; LM, Longissmus muscle; Non-OVX, Nonovariectomized (intact); OS, Ostarine; OVX, Ovariectomized; OVX+LG, Treatment groups with Ligandrol; OVX+OS, Treatment groups with Ostarine; PAS reaction, Periodic acid-Schiff reaction; SARMs, Selective androgen receptor modulators; SM, Soleus muscle; STO, Slow-twitch oxidative (fiber type I). an increase in the lean body mass in young healthy patients has been observed (27).

OS and LG are still being investigated in clinical trials, and neither have been approved as treatments to this point $(28,29)$. There are no studies reporting in vivo effects of OS and LG on postmenopausal muscle structure and metabolism. The aim of the present study was to investigate the effect of OS and LG on the muscle tissue of ovariectomized rats as the standard model for postmenopausal conditions $(30,31)$. Two independent experiments were conducted. The OS effect on bone tissue and animal model as a part of Experiment I has been recently published $(32,33)$.

\section{MATERIALS AND METHODS}

\section{General Procedures}

The animal study protocol was approved by the local regional government (14/1396, Oldenburg, Germany) in accordance with German animal protection laws prior to performing the study. Three-month old Sprague-Dawley rats (Fa. Janvier Labs, SaintBerthevin, France) were ovariectomized (OVX) or left intact (Non-OVX). Changes in musculoskeletal system caused by estrogen deficiency are known to develop in rats after at least 4-6 weeks post-OVX $(30,31)$. The treatments with OS were initiated 8 weeks after OVX and with LG after nine weeks according to the design of the two experiments (Figure 1). Three to four rats were housed in cages (Type Makrolon ${ }^{\circledR}$ IV, Techniplast Deutschland $\mathrm{GmbH}$, Hohenpreißenberg, Deutschland), four cages per treatment group.

In Experiment I, the effect of the SARM OS on the muscle structure and metabolism was studied. Rats were randomly divided into five groups (Figure 1): Group 1: Non-OVX $(n=12)$; Group 2: OVX $(n=12)$; Groups 3 to 5: OVX rats treated with OS at three different dosages of $0.04,0.4$, and $4 \mathrm{mg} / \mathrm{kg} /$ body weight (BW) $(\mathrm{OVX}+\mathrm{OS} 0.04[n=13]$, OVX+OS $0.4[n=13])$, and OVX+OS $4[n=13])$, respectively). Data on BW, uterine weight, muscle weight, and OS dosages have been previously published $(32,33)$.

In Experiment II, the effect of SARM LG on the muscle was studied. Rats were divided into five groups (Figure 1): Group 1: Non-OVX ( $n=15)$; Group $2(n=15)$ : OVX; and Groups 3 to 5 : OVX rats were treated with LG at three different dosages of 0.04 , 0.4 , and $4 \mathrm{mg} / \mathrm{kg} / \mathrm{BW}(\mathrm{OVX}+\mathrm{LG} 0.04$ [ $n=15]$, OVX+LG 0.4 [ $n$ $=15]$ ), and OVX+LG $4[n=15]$, respectively).

In both experiments, a low dosage of $0.04 \mathrm{mg} / \mathrm{kg}$ BW/day was calculated based on a human-equivalent dose sufficient for improvements of total lean body mass and physical function (24). To investigate dose-dependent effects, 10 -fold and 100-fold dosages were used. The treatments with SARMs were conducted for up to 5 weeks (Figure 1).

All rats received a soy-free rodent diet (ssniff Spezial Diät $\mathrm{GmbH}$, Soest, Germany) throughout the experiment. OS and LG were supplied with the soy-free diet (ssniff Spezial Diät GmbH). The OS (MK-2866) was obtained from Shanghai Biochempartner Co., Ltd. (Shanghai, China), whereas the LG (LGD-4033) was obtained from Hölzel Diagnostika Handels GmbH (Cologne, Germany). All rats received food and demineralized water 


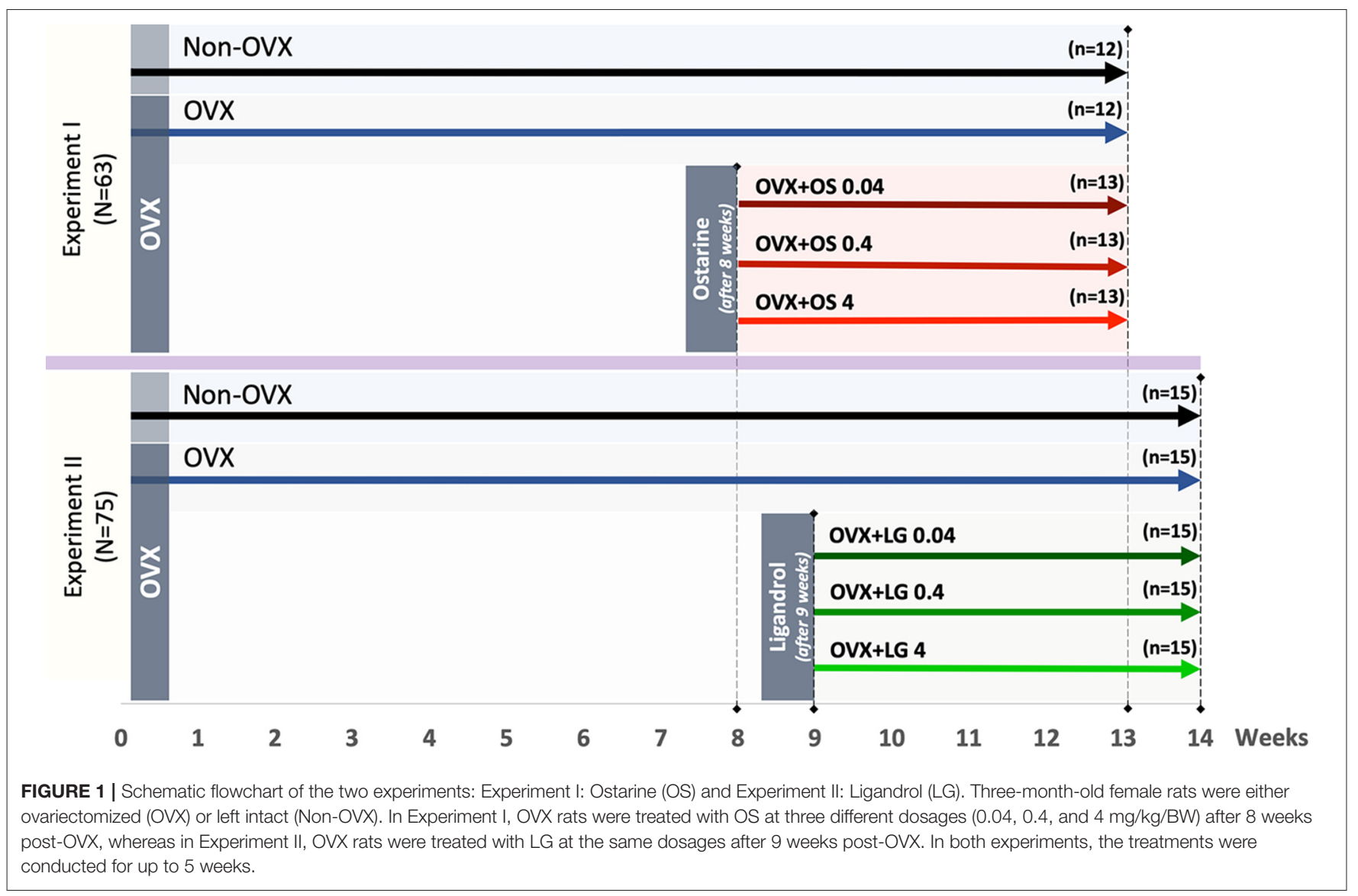

ad libitum. Food intake and BW were recorded weekly. The remaining food in the cage was weighed weekly to calculate the average daily food intake of a rat by dividing these data by days between the weighing and number of rats in a cage. The average daily dosage of OS and LG was calculated based on the daily food intake and the mean BW in the cage on the respective week (34). After 13 weeks post-OVX, all animals were euthanized under $\mathrm{CO}_{2}$ anesthesia. Blood serum was collected for further analysis of creatine kinase (CK) as a marker of muscle damage (35). The uterus was weighed. The gastrocnemius muscle (GM), soleus muscle (SM), and longissimus muscle (LM) were extracted. The GM and SM were weighed and all muscles were frozen in liquid nitrogen (36) and stored at $-80^{\circ} \mathrm{C}$ until further analyses. Either left or right muscles were used randomly in either histological or enzyme analyses. In Experiment II, intramuscular fat content was determined in the quadriceps femoris muscle in Non-OVX, OVX, and OVX+LG 4 groups.

\section{Histological Analyses}

Two staining methods were applied for analyses of muscle capillaries and muscle fibers. Serial cross-sections of a $12-\mu \mathrm{m}$ thickness were cut from the middle part of each muscle using a cryotome (CM 1900; Leica Microsystems, Wetzler, Germany) at $-20^{\circ} \mathrm{C}$, air-dried, and stored at $-20^{\circ} \mathrm{C}$ for further stainings. All chemicals were obtained from Merck KGaA (Darmstadt, Germany) unless otherwise indicated.

\section{Staining of Muscle Capillaries}

Staining of muscle capillaries was performed using a modified periodic acid-Schiff (PAS) reaction (37). A fixative solution (ethanol/chloroform/glacial acid in a 16:3:1 ratio) was applied on the serial cross-sections for $1 \mathrm{~h}$ at $4^{\circ} \mathrm{C}$ and subsequently for $10 \mathrm{~min}$ at room temperature. Sections were washed 10 times with distilled water. Next, a-Amylase from porcine pancreas (Sigma-Aldrich Laborchemikalien GmbH, Seelze, Deutschland) in $0.3 \%(\mathrm{w} / \mathrm{v})$ water solution was used for $25 \mathrm{~min}$ at $37^{\circ} \mathrm{C}$ for hydrolyzation of polysaccharides. The sections were then repeatedly washed 10 times with distilled water. Next, the PAS reaction was performed: (1) periodic acid of $1 \%(\mathrm{w} / \mathrm{v})$ was applied for $30 \mathrm{~min}$, (2) sections were washed 10 times with distilled water, and (3) Schiff's reagent solution (Roth, Karlsruhe, Germany) was applied for several minutes (2-25 min) under visual control to avoid overstaining. Following that, washing was performed in three steps: treatment with $10 \%(\mathrm{w} / \mathrm{v})$ potassium sulfite $/ 1 \mathrm{~N}$ $\mathrm{HCl} /$ water $(1: 1: 20)(30 \mathrm{~min})$, running tap water $(10 \mathrm{~min})$, and distilled water $(3 \mathrm{~min})(38,39)$.

\section{Staining of Muscle Fibers}

A fixative solution consisting of $1 \%(\mathrm{v} / \mathrm{v})$ paraformaldehyde solution ( $\mathrm{pH} 6 \cdot 6$ ), $1 \%(\mathrm{w} / \mathrm{v}) \mathrm{CaCl}_{2}$, and $6 \%(\mathrm{w} / \mathrm{v}$ ) sucrose (40) was applied for $1 \mathrm{~min}$. Sections were washed with distilled water twice for five min each. Afterwards, a modified staining method with adenosine-triphophatase (ATPase) was performed as described 
by Horák (41): (1) Incubation: diaphorase solution $(2.4 \mathrm{mM}$ $\mathrm{NADH}, 27 \mathrm{mM}$ phosphate buffer [pH 7.4], and $0.4 \mathrm{mM}$ nitro blue tetrazolium chloride), at $37^{\circ} \mathrm{C}$, humidified atmosphere, $60 \mathrm{~min}$; (2) Washing (distilled water, $15 \mathrm{~min}$ ); (3) Pre-incubation: $18 \mathrm{mM}$ $\mathrm{CaCl}_{2}$ plus $0.4 \%(\mathrm{v} / \mathrm{v})$ glacial acetic acid, $\mathrm{pH} 4.2,15 \mathrm{~min}$; (4) Washing (100 mM Tris(hydroxymethyl)aminomethane (Tris) plus $18 \mathrm{mM} \mathrm{CaCl}_{2}, \mathrm{pH} 7.8,2 \mathrm{~min}$ ); (5) ATPase incubation: $0.1 \mathrm{M}$ glycine ( $\mathrm{pH} 9.4$ ), $18 \mathrm{mM} \mathrm{CaCl}_{2}, 48.8 \mathrm{mM} \mathrm{KCl}, 2.8 \mathrm{mM}$ ATP, $37^{\circ} \mathrm{C}$, $30 \mathrm{~min}$; (6) Washing $\left(3 \times 30 \mathrm{~s}\right.$ with $\left.68 \mathrm{mM} \mathrm{CaCl}_{2}\right)$; (7) Incubation: $84 \mathrm{mM}$ cobalt chloride, $2 \mathrm{~min}$; (8) Washing $(3 \times$ $45 \mathrm{~s}$ with distilled water); (9) Incubation: $0.08 \%$ (v/v) ammonium sulfide solution, $2 \mathrm{~min}$; and (10) Washing $(1 \times 10 \mathrm{~min}$ with running tap water, $1 \times 5 \mathrm{~min}$ immersing in distilled water) $(38,39)$.

\section{Microscopy and Analysis of Muscles}

Capillaries and fibers were analyzed at 10-fold magnification (Eclipse E 600 microscope; Nikon, Tokyo, Japan), digital camera (DS-Fi2 Digital Camera; Nikon Instruments Europe,
Amsterdam, Netherlands), and analyzed digitally (NIS-Elements AR 4.0 imaging software; Nikon Instruments Europe). Evaluation of fibers was performed in three randomly chosen fields of $1 \mathrm{~mm}^{2}$ in the ATPase stained sections. Ninety slow-twitch oxidative and fast-twitch oxidative (STO and FTO; fiber types I and IIa) and 90 fast-twitch glycolytic (FTG; fiber type IIb) fibers were skirted (42). Since SM consists mainly of STO and FTO fibers, only these fibers were measured (43). Fiber contours were manually defined in digital images. Distribution of fibers was analyzed within a $1 \mathrm{~mm}^{2}$ field by calculating the percentage of STO+FTO and FTG fibers in LM. Evaluation of capillaries was performed in two randomly chosen fields of $0.25 \mathrm{~mm}^{2}$ in the amylase-PAS stained sections. The ratio of capillaries to fibers was calculated (capillary density) (44).

\section{Analysis of Muscle Enzyme Activity}

For analysis of muscle enzyme activities (lactate dehydrogenase $[\mathrm{LDH}]$, citrate synthase [CS], and Complex I) samples were powdered (Mikro-Dismembrator S; Satorius ${ }^{\circledR}$, Göttingen,

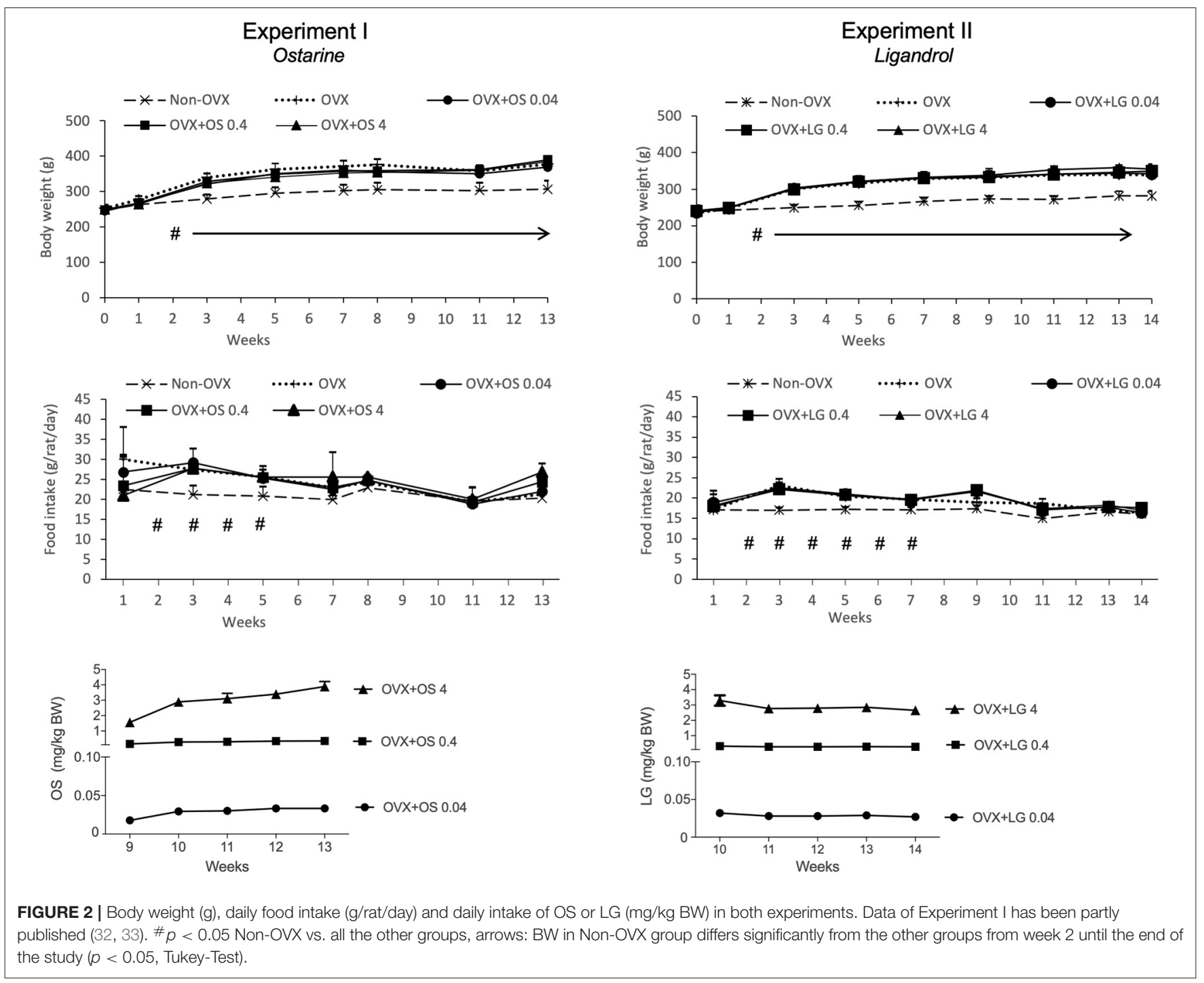


TABLE 1 | Data of Experiment I: Ostarine (OS).

\begin{tabular}{|c|c|c|c|c|c|c|c|c|c|c|c|c|c|c|c|}
\hline \multirow{3}{*}{$\begin{array}{l}\text { Groups } \\
\text { Sample size } \\
\text { Parameters }\end{array}$} & \multirow{2}{*}{\multicolumn{2}{|c|}{$\begin{array}{c}\text { Non-OVX } \\
12\end{array}$}} & \multirow{2}{*}{\multicolumn{3}{|c|}{$\begin{array}{c}\text { ovx } \\
12\end{array}$}} & \multirow{2}{*}{\multicolumn{3}{|c|}{$\frac{o v X+O S 0.04}{13}$}} & \multirow{2}{*}{\multicolumn{3}{|c|}{$\frac{\text { ovX }+0 S 0.4}{13}$}} & \multirow{2}{*}{\multicolumn{3}{|c|}{$\frac{\text { ovX }+ \text { os } 4}{13}$}} & \multirow{3}{*}{$\begin{array}{l}\text { ANOVA } \\
p \text {-value }\end{array}$} \\
\hline & & & & & & & & & & & & & & & \\
\hline & Mean & SD & Mean & & SD & Mean & & SD & Mean & & SD & Mean & & SD & \\
\hline \multicolumn{16}{|l|}{ Weights $(32,33)$} \\
\hline Body weight (begin of trial) [g] & 247.42 & 6.09 & 244.33 & & 9.77 & 241.08 & & 8.98 & 244.54 & & 6.55 & 241.15 & & 6.08 & 0.210 \\
\hline Body weight (begin of treatment) [g] & 305.40 & 21.69 & 375.60 & a & 12.27 & 356.11 & a & 18.00 & 360.50 & a & 21.13 & 353.00 & a & 28.62 & $<0.001$ \\
\hline Body weight (end of trial) $[g]$ & 307.20 & 29.12 & 376.56 & a & 19.18 & 368.91 & a & 23.91 & 389.70 & a & 32.44 & 385.30 & a & 25.14 & $<0.001$ \\
\hline Uterus weight [g] & 0.52 & 0.10 & 0.10 & a & 0.04 & 0.11 & a & 0.03 & 0.33 & $a b c$ & 0.06 & 0.40 & $\mathrm{abc}$ & 0.06 & $<0.001$ \\
\hline GM weight [g] & 1.87 & 0.27 & 2.02 & & 0.26 & 2.21 & a & 0.29 & 2.26 & a & 0.26 & 2.27 & a & 0.24 & 0.005 \\
\hline GM weight/BW [mg/g] & 6.08 & 0.88 & 5.38 & & 0.69 & 6.00 & & 0.78 & 5.79 & & 0.66 & 5.88 & & 0.63 & 0.280 \\
\hline SM weight $[g]$ & 0.15 & 0.03 & 0.15 & & 0.02 & 0.16 & & 0.02 & 0.18 & & 0.03 & 0.17 & & 0.02 & 0.047 \\
\hline SM weight/BW [mg/g] & 0.48 & 0.09 & 0.41 & & 0.05 & 0.44 & & 0.05 & 0.45 & & 0.08 & 0.44 & & 0.05 & 0.246 \\
\hline \multicolumn{16}{|l|}{ Muscle fibers } \\
\hline \multicolumn{16}{|l|}{ GM } \\
\hline \multicolumn{16}{|l|}{ STO+FTO } \\
\hline Area $\left(\mu \mathrm{m}^{2}\right)$ & 1863.17 & 400.70 & 2222.06 & & 483.36 & 1985.55 & & 240.70 & 2269.35 & & 371.32 & 2248.09 & & 551.21 & 0.125 \\
\hline Diameter $(\mu \mathrm{m})$ & 48.04 & 5.30 & 52.42 & & 6.00 & 49.78 & & 3.02 & 53.07 & & 4.28 & 52.74 & & 6.00 & 0.117 \\
\hline \multicolumn{16}{|l|}{ FTG } \\
\hline Area $\left(\mu m^{2}\right)$ & 4587.12 & 374.38 & 4691.65 & & 735.21 & 5025.66 & & 672.28 & 5463.72 & & 1284.49 & 5397.56 & & 1146.98 & 0.124 \\
\hline Diameter $(\mu \mathrm{m})$ & 75.82 & 3.18 & 76.43 & & 6.34 & 79.27 & & 5.31 & 82.34 & & 8.77 & 81.93 & & 8.65 & 0.117 \\
\hline \multicolumn{16}{|c|}{ LM } \\
\hline \multicolumn{16}{|l|}{ STO+FTO } \\
\hline Area $\left(\mu \mathrm{m}^{2}\right)$ & 1904.72 & 404.03 & 2226.74 & & 437.36 & 2385.09 & & 725.93 & 2476.78 & & 608.82 & 2469.54 & & 345.07 & 0.098 \\
\hline Diameter $(\mu \mathrm{m})$ & 48.57 & 5.11 & 52.44 & & 5.22 & 53.95 & & 7.90 & 55.08 & & 6.94 & 55.38 & & 3.87 & 0.087 \\
\hline \multicolumn{16}{|l|}{ FTG } \\
\hline Area $\left(\mu \mathrm{m}^{2}\right)$ & 4634.02 & 734.27 & 5258.92 & & 858.52 & 5624.63 & & 1518.75 & 5830.73 & & 1065.73 & 5731.07 & & 768.68 & 0.082 \\
\hline Diameter $(\mu \mathrm{m})$ & 76.19 & 6.25 & 81.21 & & 6.44 & 83.43 & & 11.10 & 85.45 & & 7.97 & 84.79 & & 5.70 & 0.072 \\
\hline \multicolumn{16}{|l|}{ SM } \\
\hline \multicolumn{16}{|l|}{ STO } \\
\hline Area $\left(\mu \mathrm{m}^{2}\right)$ & 3665.93 & 501.22 & 3568.44 & & 506.04 & 3973.02 & & 478.48 & 3609.49 & & 438.43 & 4175.71 & & 778.99 & 0.072 \\
\hline Diameter $(\mu \mathrm{m})$ & 67.57 & 4.66 & 66.74 & & 4.85 & 70.44 & & 4.37 & 67.23 & & 4.01 & 72.05 & & 6.66 & 0.084 \\
\hline \multicolumn{16}{|l|}{ Percentage of fibers (\%) } \\
\hline STO+FTO & 42.5 & 10.3 & 47.7 & & 8.5 & 43.8 & & 9.8 & 45.1 & & 3.6 & 46.4 & & 3.7 & 0.689 \\
\hline FTG & 57.5 & 10.3 & 52.3 & & 8.5 & 56.2 & & 9.8 & 54.9 & & 3.6 & 53.6 & & 3.7 & 0.689 \\
\hline \multicolumn{16}{|l|}{ Creatine kinase } \\
\hline Serum CK level (U/I) & 5775.90 & 2001.34 & 6096.67 & & 1960.97 & 9492.10 & & 1691.25 & 6018.50 & & 1599.74 & 6145.90 & & 1456.36 & 0.927 \\
\hline
\end{tabular}

Tukey test.

${ }^{a} p<0.05$ vs. Non-OVX

${ }^{b} p<0.05$ vs. OVX.

${ }^{c} p<0.05$ vs. OVX+OS 0.04 .

$S D$, Standard deviation. 

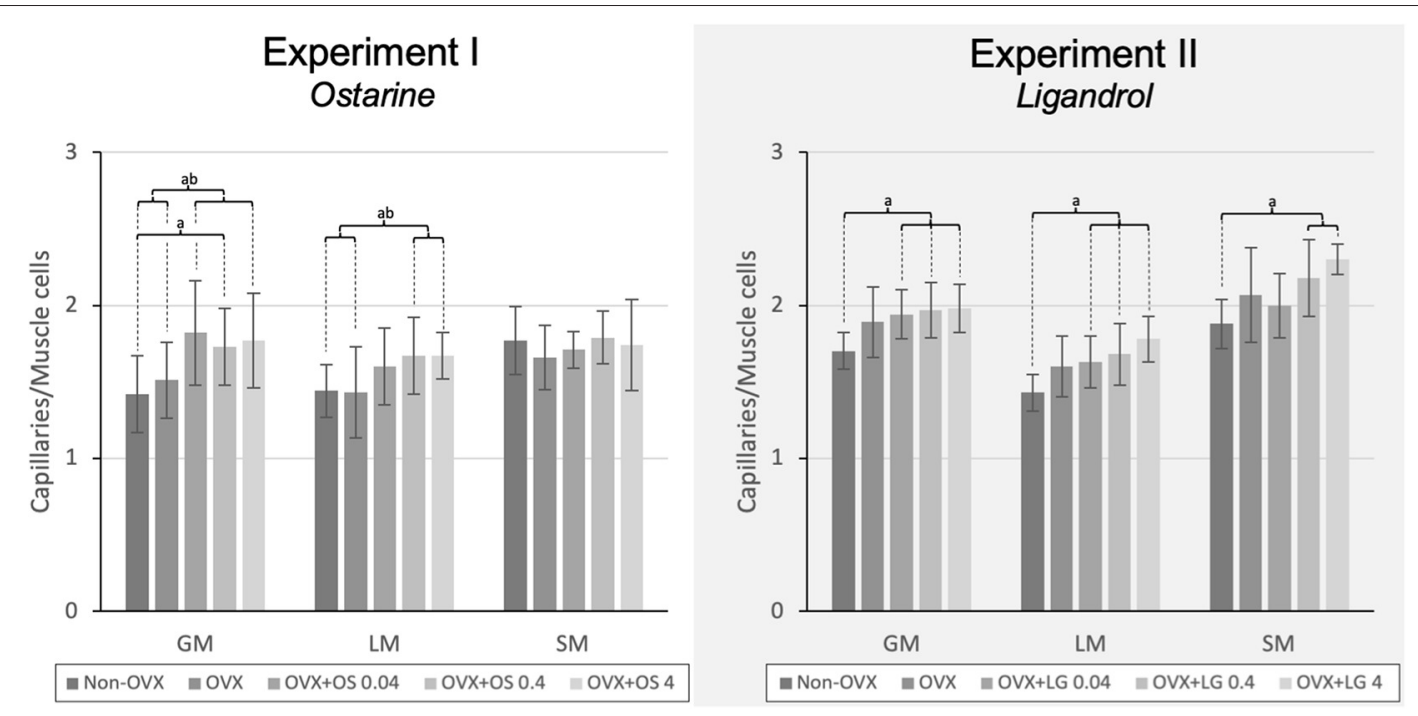

FIGURE 3 | The capillary density in the LM, GM, and SM in Experiment I: Ostarine (OS) and Experiment II: Ligandrol (LG). Tukey test: a: $p<0.05$ vs. Non-OVX, b: $p<$ 0.05 vs. OVX, c: $p<0.05$ vs. OVX+OS 0.04 , d: $p<0.05$ vs. OVX+OS 0.4 .

Deutschland), and subsequently homogenized in ice-cold Chappel-Perry medium $(0.1 \mathrm{M}$ of $\mathrm{KCl}, 0.05 \mathrm{M}$ of Tris, $0.01 \mathrm{M}$ of $\mathrm{MgCl}_{2}-6 \mathrm{H}_{2} \mathrm{O}, 1 \mathrm{mM}$ of EGTA, pH 7.5) (45). Muscle enzyme activity was measured via photometry (Libra; Biochrom Ltd. ${ }^{\circledR}$, Cambridge, England). Analysis of LDH activity was performed as described previously (45). Faloona and Srere's approach (46) was applied for measurement of CS and Hatefi and Stiggall's method (47) for Complex I. A BCA Protein Assay Kit (Pierce, Rockford, IL, USA) and a multilabel reader (PerkinElmer Precisely Victor X4 ver. 4.0; PerkinElmer Life and Analytical Science, Turku, Finland) were used to calculate protein content in muscle fibers. Muscle enzyme activity was determined in relation to protein content.

In serum, analysis of CK activity was conducted at the Department of Clinical Chemistry, University of Goettingen using automated chemistry analyzer Architect c16000 (Abbott ${ }^{\circledR}$, Wiesbaden, Deutschland) and commercially available kits (Abbott) according to the manufacturer's instructions (Abbott). The method with $\mathrm{N}$-acetyl-L-cysteine as the enzyme reactivator was applied (7D63-30, Abbott).

\section{Analysis of Intramuscular Fat Content}

According to the International Organization for Standardization method 1443:1973, 5-10g of the homogenized quadriceps femoris muscle were boiled in hydrochloric acid ( $\mathrm{HCl})(4 \mathrm{M})$ for $1.5 \mathrm{~h}$ to free the occluded and bound lipid fractions. After filtration of the resulting mass and drying, the content of the filter was extracted with light petroleum for $4 \mathrm{~h}$ using a Soxhlet apparatus (LAT $\mathrm{GmbH}$, Garbsen, Germany). The fat content was determined as percentage of wet weight of sample taken for the analysis.

\section{Statistical Analysis}

Statistical analyses were performed with GraphPad Prism ver. 8.2.1 (GraphPad Software, San Diego, CA, USA). For parametric data, a one-way analysis of variation (ANOVA) was used to reveal the impact of the treatments. The differences among the groups were analyzed by applying Tukey's post-hoc test. For nonparametric data, the Kruskal-Wallis test and the Dunn test were applied. The $p$-values less than 0.05 were considered significant. Data are presented as means and standard deviations.

\section{RESULTS}

\section{Experiment I: Ostarine OS Dosage and Food Intake}

The average daily uptake of OS calculated based on the food intake and BW on the respective week was $0.03 \pm 0.006$ $\mathrm{mg} / \mathrm{kg} / \mathrm{BW}$ in the OVX+OS 0.04 group, $0.3 \pm 0.07 \mathrm{mg} / \mathrm{kg} / \mathrm{BW}$ in the OVX+OS 0.4 group, and $3.0 \pm 0.83 \mathrm{mg} / \mathrm{kg} / \mathrm{BW}$ in the OVX+OS 4 group. The average daily food intake was $22.3 \pm$ $4.6 \mathrm{~g} / \mathrm{rat} /$ day in all groups (33). Rats in the Non-OVX group consumed less food during weeks 2 to 5 than rats in all the other groups (Figure 2).

\section{Weight of the Body, Uterus, and Muscle}

The BW of the rats across all treatment groups was similar at the beginning of the study $(244 \pm 7.8 \mathrm{~g})(32,33)$. Ovariectomy led to a significant enhancement of BW in all four OVX groups compared with the Non-OVX group from week 2 post ovariectomy. Treatment with OS did not have any influence on body weight (Table 1, Figure 2) (32, 33).

In all four OVX groups, uterine weight was significantly lower compared with the Non-OVX group (Non-OVX group: $0.52 \pm$ $0.10 \mathrm{~g}$; OVX group: $0.10 \pm 0.04 \mathrm{~g})(32,33)$. In the OVX+OS 0.04 group, uterine weight did not differ from that in the OVX group, whereas in groups OVX+OS 0.4 and OVX+OS 4 it was significantly higher than in the OVX and OVX+OS 0.04 groups (Table 1) (32, 33). 


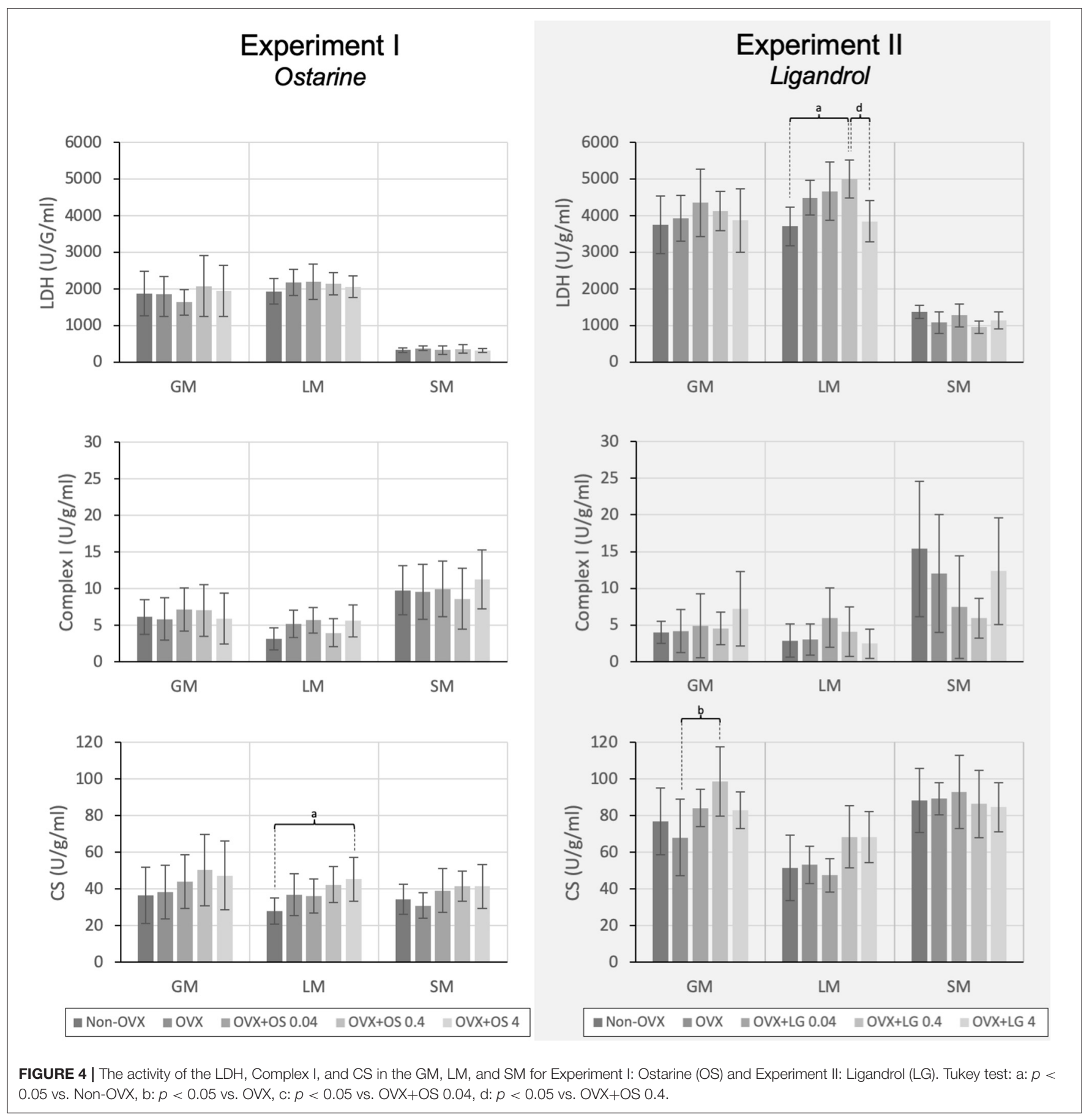

The treatments with OS resulted in a significantly higher weight of the GM than in the Non-OVX, irrespective of dosages applied. The weight of the SM did not differ between the groups. After correction by BW, the effects were not significant (Table 1) (32).

\section{Vascularization of Muscles}

The treatment with OS resulted in a higher capillary density in GM and LM. In the GM, all OS treatments showed a higher capillary density compared with that in the Non-OVX group.
In the OVX+OS 0.04 and OVX+OS 4 groups, a significantly higher capillary density was found than in the OVX group. In the LM, a significantly higher capillary density was observed in the OVX+OS 0.4 and OVX+OS 4 treatment groups than in the Non-OVX and OVX groups. In the SM, OS treatment did not change the number of capillaries (Figure 3).

\section{Muscle Fiber Size and Distribution}

The treatments with OS did not result in significant alterations of the area or the corresponding diameter of STO/FTO and FTG 
fibers of GM, LM, or SM compared with the Non-OVX and the OVX groups. This was independent of the OS dosage. Regarding the distribution of muscle fibers in LM (FTG and STO/FTO), there were no differences (Table 1).

\section{Activity of Enzymes in Muscle and Serum}

The treatment with OS resulted in a significantly higher activity of CS in the LM in the OVX+OS 4 treatment group than in the Non-OVX group (Figure 4). This effect was not observed in the GM or the SM. LDH and Complex I activities did not differ among the groups in all three muscles studied. Serum CK levels were not changed following OS treatments after OVX (Table 1).

\section{Experiment II: LG \\ LG Dosage and Food Intake}

The daily dosage of LG was calculated based on the food intake and BW at the respective week and averaged: $0.03 \pm 0.002$ $\mathrm{mg} / \mathrm{kg} / \mathrm{BW}$ in the OVX+LG 0.04 group, $0.3 \pm 0.03 \mathrm{mg} / \mathrm{kg} / \mathrm{BW}$ in the OVX+LG 0.4 group, and $3.0 \pm 0.27 \mathrm{mg} / \mathrm{kg} / \mathrm{BW}$ in the OVX+LG 4 group. The average daily food intake was $19.0 \pm 2.1 \mathrm{~g} / \mathrm{rat} / \mathrm{day}$ in all groups. The food intake of NonOVX rats was lower than in all the other groups on weeks 2 to 7 (Figure 2).

\section{Weight of the Body, Uterus, and Muscle}

At the beginning of the study, the rats of all treatment groups had a similar BW (237 $\pm 11.7 \mathrm{~g})$. From week 2 , the Non-OVX animals weighed significantly less than all other rats that underwent the OVX operation. This difference remained until the end of the study, irrespective of LG treatments (Table 2, Figure 2).

A significantly lower uterine weight was observed in all four OVX groups compared with the Non-OVX group (NonOVX group: $0.58 \pm 0.11 \mathrm{~g}$; OVX group: $0.11 \pm 0.02 \mathrm{~g}$ ). LG treatments in the OVX+LG 0.04 and OVX+LG 0.4 groups did not change the uterine weight. In the OVX+LG 4 group, the weight was significantly higher compared with the OVX group and the OVX+LG 0.04 and OVX+LG 0.4 treatment groups (Table 2 ).

All four OVX groups showed a significantly higher GM weight than in the Non-OVX group. Treatment with a high dose of LG resulted in a significantly higher GM weight than in the OVX and OVX+LG 0.04 groups. The weight of the SM did not differ among the groups. After correction by BW, there were no significant effects (Table 2).

\section{Vascularization of Muscles}

The treatments with LG resulted in a higher number of capillaries in all muscles studied. In the GM and the LM, all LG treated groups showed a significantly higher capillary density than in the Non-OVX group. In the SM, this effect was observed in the OVX+LG 0.4 and OVX+LG 4 groups (Figure 3).

\section{Muscle Fiber Size and Distribution}

In the LM, the area and the corresponding diameter of STO/FTO and FTG fibers were significantly larger in the OVX+LG 4 group compared with the Non-OVX group. In the SM, a significantly larger area and corresponding diameter of STO/FTO fibers were observed in the OVX and OVX+LG 0.4 groups than in the Non-OVX group. Additionally, the diameter of these fibers in the SM was significantly larger in OVX+LG 4 group than in the Non-OVX group. In the $\mathrm{GM}$, no differences were observed. The distribution of muscle fibers (FTG and STO/FTO) in LM did not differ among the groups (Table 2).

\section{Activity of Enzymes in Muscle and Serum}

In the GM, a significantly higher activity of CS was observed in the OVX+LG 0.4 treatment group than in the OVX group. The activity of other muscle enzymes in the GM did not differ among the treatment groups. In the LM, the treatment with LG showed significantly higher LDH activity in the OVX+LG 0.4 group than in the Non-OVX and the OVX+LG 4 groups. In the $\mathrm{SM}$, there were no differences among the treatment groups in all three enzymes studied (Figure 4). The treatment with LG or OVX did not change the serum CK levels (Table 2).

\section{Intramuscular Fat}

A significantly higher intramuscular fat content of the quadriceps femoris muscle was observed in the OVX+LG 4 group compared with the Non-OVX group. In OVX rats, the fat content of the muscle did not differ from that in the other groups (Table 2).

\section{DISCUSSION}

This study determined the effects of the treatment with the OS and LG on the muscle tissue and metabolism of ovariectomized rats as a standard model for postmenopausal osteoporosis. Both SARMs resulted in a higher muscles' vascularization in terms of a higher capillary density and elevated muscle enzymes' activity, having no hypertrophic effect on muscle fibers.

In both experiments, BW increased significantly after OVX $(32,33)$, that is a known response to estrogen deprivation in rats $(32,33,48,49)$ and can be explained by enhanced food intake and other metabolic changes in these rats (50). None of the treatments with the SARMs altered the BW and food intake, and that is in line with previous reports $(32,51)$. In contrast, Kearbey, Gao (52) observed a higher BW in OVX rats after administration of the SARM S-4 than in OVX rats. It is possible that the changes in BW depend on the specific SARM being studied (32).

Similar to the BW, the weight of the GM was higher in all OVX rats than in Non-OVX in both experiments. This appeared to be a consequence of the estrogen deprivation $(48,49,53)$. Only the OVX+LG 4 treatment group showed a higher GM's weight than in the OVX and OVX+LG 0.4 groups, which is in line with the observation of increased intramuscular fat in the OVX+LG 4 group. OS has been shown to increase lean body mass and decrease total fat mass (24). However, as a higher intramuscular fat content after treatment with LG has not been reported to the best of our knowledge so far, this impact of a SARM application has to be considered as a possible side effect. Since the analysis of intramuscular fat content is very complex and was not the main focus of the 
TABLE 2 | Data of Experiment II: Ligandrol (LG).

\begin{tabular}{|c|c|c|c|c|c|c|c|c|c|c|c|c|c|c|c|}
\hline \multirow{3}{*}{$\begin{array}{l}\text { Groups } \\
\text { Sample Size } \\
\text { Parameters }\end{array}$} & \multirow{2}{*}{\multicolumn{2}{|c|}{$\begin{array}{c}\text { Non-OVX } \\
12 \\
\end{array}$}} & \multicolumn{3}{|c|}{ ovx } & \multicolumn{3}{|c|}{ OVX+LG 0.04} & \multicolumn{3}{|c|}{ OVX+LG 0.4} & \multicolumn{3}{|c|}{ OVX+LG 4} & \multirow{3}{*}{$\begin{array}{l}\text { ANOVA } \\
\mathrm{p} \text {-value }\end{array}$} \\
\hline & & & \multicolumn{3}{|c|}{12} & \multicolumn{3}{|c|}{13} & \multicolumn{3}{|c|}{13} & \multicolumn{3}{|c|}{13} & \\
\hline & Mean & SD & Mean & & SD & Mean & & SD & Mean & & SD & Mean & & SD & \\
\hline \multicolumn{16}{|l|}{ Weights } \\
\hline Body weight (begin of trial) [g] & 239.20 & 10.92 & 235.00 & & 10.69 & 237.00 & & 12.17 & 240.50 & & 14.53 & 236.64 & & 10.54 & 0.742 \\
\hline Body weight (begin of treatment) [g] & 273.00 & 11.90 & 332.27 & a & 17.21 & 335.40 & a & 19.81 & 333.43 & a & 25.40 & 337.57 & a & 31.44 & $<0.001$ \\
\hline Body weight (end of trial) $[g]$ & 282.47 & 14.81 & 338.67 & a & 20.53 & 342.13 & $\mathrm{a}$ & 27.41 & 350.39 & a & 16.33 & 355.21 & $a$ & 19.37 & $<0.001$ \\
\hline Uterus weight $[g]$ & 0.58 & 0.11 & 0.11 & a & 0.02 & 0.11 & a & 0.02 & 0.13 & a & 0.02 & 0.43 & $\mathrm{abcd}$ & 0.04 & $<0.001$ \\
\hline GM weight [g] & 2.03 & 0.14 & 2.29 & a & 0.14 & 2.30 & a & 0.23 & 2.45 & a & 0.20 & 2.49 & $a b c$ & 0.17 & $<0.001$ \\
\hline GM weight/BW [mg/g] & 7.20 & 0.51 & 6.71 & & 0.41 & 6.69 & & 0.68 & 7.06 & & 0.57 & 6.94 & & 0.47 & 0.059 \\
\hline SM weight [g] & 0.11 & 0.02 & 0.12 & & 0.02 & 0.12 & & 0.03 & 0.13 & & 0.02 & 0.11 & & 0.03 & 0.619 \\
\hline $\mathrm{SM}$ weight/BW [mg/g] & 0.41 & 0.07 & 0.32 & & 0.11 & 0.34 & & 0.08 & 0.36 & & 0.07 & 0.31 & & 0.07 & 0.016 \\
\hline \multicolumn{16}{|l|}{ Muscle fibers } \\
\hline \multicolumn{16}{|l|}{ GM } \\
\hline \multicolumn{16}{|l|}{ STO+FTO } \\
\hline Area $\left(\mu \mathrm{m}^{2}\right)$ & 2810.58 & 722.26 & 2781.12 & & 432.03 & 2631.86 & & 440.71 & 2888.26 & & 517.74 & 2895.14 & & 496.48 & 0.812 \\
\hline Diameter $(\mu \mathrm{m})$ & 58.75 & 7.28 & 58.69 & & 4.43 & 57.09 & & 4.55 & 60.23 & & 5.50 & 58.72 & & 5.44 & 0.734 \\
\hline \multicolumn{16}{|l|}{ FTG } \\
\hline Area $\left(\mu \mathrm{m}^{2}\right)$ & 5149.24 & 1457.48 & 5263.84 & & 897.71 & 5128.98 & & 975.04 & 5587.79 & & 958.43 & 5950.49 & & 951.88 & 0.296 \\
\hline Diameter $(\mu \mathrm{m})$ & 79.64 & 10.95 & 81.03 & & 6.97 & 79.73 & & 7.71 & 83.54 & & 7.01 & 85.95 & & 6.70 & 0.263 \\
\hline \multicolumn{16}{|l|}{ LM } \\
\hline \multicolumn{16}{|l|}{$\mathrm{STO}+\mathrm{FTO}$} \\
\hline Area $\left(\mu \mathrm{m}^{2}\right)$ & 1921.24 & 381.27 & 2154.24 & & 507.73 & 2240.71 & & 428.29 & 2282.34 & & 289.65 & $2561.80^{a}$ & & 589.89 & 0.018 \\
\hline Diameter $(\mu \mathrm{m})$ & 48.77 & 4.68 & 51.37 & & 6.18 & 52.48 & & 5.24 & 53.16 & & 3.45 & $55.98^{\mathrm{a}}$ & & 6.35 & 0.024 \\
\hline \multicolumn{16}{|l|}{ FTG } \\
\hline Area $\left(\mu \mathrm{m}^{2}\right)$ & 4021.84 & 624.27 & 4574.66 & & 833.59 & 4872.13 & & 981.56 & 4647.10 & & 617.80 & 5426.81 & a & 1080.47 & 0.465 \\
\hline Diameter $(\mu \mathrm{m})$ & 70.98 & 5.40 & 75.50 & & 7.05 & 77.79 & & 7.77 & 76.24 & & 5.24 & 82.06 & a & 7.77 & 0.004 \\
\hline \multicolumn{16}{|l|}{ SM } \\
\hline \multicolumn{16}{|l|}{ STO } \\
\hline Area $\left(\mu m^{2}\right)$ & 3637.88 & 396.82 & 4186.24 & a & 470.72 & 3897.86 & & 293.80 & 4277.79 & a & 435.12 & 4106.85 & & 635.44 & 0.005 \\
\hline Diameter $(\mu \mathrm{m})$ & 66.13 & 6.24 & 72.38 & a & 4.24 & 69.87 & & 2.63 & 73.15 & a & 3.66 & 71.53 & $\mathrm{a}$ & 5.32 & 0.002 \\
\hline \multicolumn{16}{|l|}{ Percentage of fibers (\%) } \\
\hline STO+FTO & 46.9 & 4.6 & 43.8 & & 4.4 & 43.3 & & 4.1 & 43.9 & & 5.2 & 45.4 & & 5.3 & 0.277 \\
\hline FTG & 53.1 & 4.6 & 56.2 & & 4.4 & 56.7 & & 4.1 & 56.1 & & 5.2 & 54.6 & & 5.3 & 0.277 \\
\hline Creatine kinase & & & & & & & & & & & & & & & \\
\hline Serum CK level (U/l) & 5843.60 & 1520.58 & 7545.07 & & 3510.27 & 5601.20 & & 1834.22 & 5202.38 & & 1960.71 & 5598.29 & & 1929.49 & 0.061 \\
\hline Percentage of intramuscular fat & & & & & & & & & & & & & & & \\
\hline Quadriceps femoris muscle & $1.66(1$ & $8,1.88)$ & 1.78 & $(1.64$ & 1.90) & & & & & & & 1.94 & 1.82 & a & 0.026 \\
\hline
\end{tabular}

Tukey test.

${ }^{a} p<0.05$ vs. Non-/OVX

$b_{p}<0.05$ vs. OVX

${ }^{c} p<0.05$ vs. OV $x+0 S 0.04$

${ }^{d} p<0.05$ vs. OVX+OS 0.4

$S D$, Standard deviation.

The percentage of intramuscular fat was non-parametric.

q1: the first quartile, which separates the lowest $25 \%$ of the data from the highest $75 \%$.

q3: the third quartile, which separates the highest $25 \%$ of the data from the lowest $75 \%$. 
study, only the groups Non-OVX, OVX and OVX+LG 4 were chosen. Albeit, only the highest dose of LG was tested, it seems to be important finding and should be investigated in the future studies.

Regarding muscle fibers, OS and LG did not change their size in the OVX rats. In the LG experiment, an enhanced fiber size was measured in the OVX, the OVX+LG 0.4, and the OVX+LG 4 groups in the SM and in the OVX+LG 4 group in the LM compared with the Non-OVX group. Increased size of muscle fibers after OVX has been observed in previous studies (53-55), whereas estrogen supplementation has been shown to have an inhibitory effect on muscle fiber diameter (55). Vajda, Hogue (51) found that, after administration of the SARM LGD-3303 in orchiectomized rats for 12 weeks, the weight of the levator ani muscle was higher than in the castrated control. Regarding the effect of testosterone, Neto, De (56) observed a larger cross-sectional area of the plantaris muscle after 15 weeks of administration than in untreated 24-month old rats. In humans, long-term testosterone administration was shown to result in a larger muscle fiber Type I area of the vastus lateralis (57). A possible reason for the absence of stronger effects on muscle fiber size in the present study could be the relative short-term administration of OS and LG.

In this study, both OS and LG showed a beneficial effect on the muscle vascularization. It is known that enhanced vascularization improves the restoration of muscle contractility (58). While an effect of increased muscle vascularization after treatment with SARMs has not yet been shown, for the administration of testosterone, a higher capillary density was observed $(56,57)$. In the present study, LG resulted in a higher vascularization in all three muscles studied, than in the Non-OVX group, whereas OS influenced the capillary density in the GM and LM compared with the Non-OVX and OVX groups. Thus, OS possessed a stronger and more specific impact on muscle vascularization than LG.

Activity of several muscle enzymes was determined. CS is the pace-making enzyme of the citric acid cycle that is considered as the central metabolic pathway under aerobic conditions (59). It is a marker for the mitochondrial content and the oxidative capacity of muscles and is increased by exercise training (60-62). LDH catalyzes the conversion of lactate to pyruvate and back through the oxidation process (NAD $+\rightleftarrows \mathrm{NADH})$. It regulates the glycolysis and is therefore essential for the cell metabolism of all nearby tissues under anaerobic conditions (63). Complex I is the first enzyme in the respiratory chain in the mitochondrial membrane and essential for the normal cell functioning. This study showed that the intermediate dosage of LG resulted in a higher activity of CS than in the OVX group in the GM and a higher activity of LDH than in the Non-OVX and OVX+LG 4 in the LM. OS had less effect on muscle enzyme activity, showing a higher CS activity in OVX+OS 4 group than in the OVX group in the LM. Whereas, an elevated CS activity is a marker for an increased aerobic capacity, an enhanced activity of both enzymes, $\mathrm{LDH}$ and $\mathrm{CS}$, seems to be necessary for a rapid muscle recovery $(58,62)$. Elevation of these enzyme activities following administration of SARMs might indicate an improved muscle function. Additionally, the present study revealed that serum $\mathrm{CK}$ as an indicator of muscle damage was not affected by either OS or LG.

Both SARMs had an uterotrophic effect at higher dosages, which indicates a reduced selectivity with increasing the dosage. The reason for the reduced tissue selectivity of SARMs caused by different scaffoldings interacting with the $\mathrm{N}$-/Cterminal domains of the androgen receptor (64). The effect on the uterus was stronger for OS than for LG, since even the intermediate dosage of OS led to a significantly higher uterine weight. A similar effect on uterine weight after administration of OS has been reported previously and represents a limitation of its application at higher doses $(32,65)$. Investigation at the cellular level showed that OS leads to an increased percentage of Ki67-positive cells in the uterine stroma of mice and a higher proliferation of epithelial cells (66). In the present study a distinct dose-dependent uterotrophic effect was observed that is in line with previous studies $(65,66)$. Correspondently to the effect in uterus, capillary density in muscle responded to the SARM treatments dose-dependently. However, the effect of different doses on other muscle parameters including metabolic enzymes was not clearly distinguished.

One of the limitations of the present study is that both SARMs were applied via food and the individual dosis could vary between the animals. On the other hand, the advantage of SARMs is their oral availability that allows easy and non-invasive administration of these substances. A further limitation is, that the experimental design lacks the effect of mechanical stimulation of muscle though the positive effect of anabolic substances on muscle size and strength as well as fat-free mass is augmented by concomitant exercise $(15,28)$. In the future studies on SARMs this aspect could be investigated.

In conclusion, the results of the present study showed beneficial effects of both SARMs on the muscle structure and metabolism in ovariectomized rats. Both OS and LG improved muscle vascularization, and OS had a stronger effect than LG on vascularization. In contrast, LG possessed more effect on muscle metabolic enzymes by elevating LDH and CS activities, whereas OS solely resulted in a high CS activity. A hypertrophic effect on muscle fiber size was not observed under either SARM treatment. However, higher muscle weight along with enhanced intramuscular fat content after LG treatment at high doses could be considered as an unfavorable side effect, and therefore more attention needs to be paid to this aspect in further studies on SARMs. Furthermore, the uterotrophic effect of both of the studied SARMs at higher dosages might be a limitation for their application.

\section{DATA AVAILABILITY STATEMENT}

The raw data supporting the conclusions of this article will be made available by the authors, without undue reservation. 


\section{ETHICS STATEMENT}

The animal study was reviewed and approved by Ethikkommission der Universitätsmedizin Göttingen, "Von-Siebold-Str.3", 37075 Göttingen.

\section{AUTHOR CONTRIBUTIONS}

Study conception, design, and financial support: SS and MK. Acquisition of data: DH and CK. Statistical analysis: DH, CK, and PR. Analysis and interpretation of data: PR, MK, and CK.

\section{REFERENCES}

1. Briggs AM, Cross MJ, Hoy DG, Sanchez-Riera L, Blyth FM, Woolf $\mathrm{AD}$, et al. Musculoskeletal health conditions represent a global threat to healthy aging: a report for the 2015 World health organization world report on ageing and health. Gerontologist. (2016) 56(Suppl. 2):S24355. doi: 10.1093/geront/gnw002

2. Chen X, Mao G, Leng SX. Frailty syndrome: an overview. Clin Interv Aging. (2014) 9:433-41. doi: 10.2147/CIA.S45300

3. Ensrud KE, Ewing SK, Taylor BC, Fink HA, Stone KL, Cauley JA, et al. Frailty and risk of falls, fracture, and mortality in older women: the study of osteoporotic fractures. J Gerontol A Biol Sci Med Sci. (2007) 62:74451. doi: 10.1093/gerona/62.7.744

4. Nowak A, Hubbard RE. Falls and frailty: lessons from complex systems. $J R$ Soc Med. (2009) 102:98-102. doi: 10.1258/jrsm.2009.080274

5. Hernlund E, Svedbom A, Ivergard M, Compston J, Cooper C, Stenmark J, et al. Osteoporosis in the European Union: medical management, epidemiology and economic burden. A report prepared in collaboration with the International osteoporosis foundation (IOF) and the European federation of pharmaceutical industry associations (EFPIA). Arch Osteoporos. (2013) 8:136. doi: 10.1007/s11657-013-0136-1

6. Cruz-Jentoft AJ, Bahat G, Bauer J, Boirie Y, Bruyere O, Cederholm T, et al. Sarcopenia: revised European consensus on definition and diagnosis. Age Ageing. (2019) 48:16-31. doi: 10.1093/ageing/afy169

7. Ikeda K, Horie-Inoue K, Inoue S. Functions of estrogen and estrogen receptor signaling on skeletal muscle. J Steroid Biochem Mol Biol. (2019) 191:105375. doi: 10.1016/j.jsbmb.2019.105375

8. Chlebowski RT, Kuller LH, Prentice RL, Stefanick ML, Manson JE, Gass M, et al. Breast cancer after use of estrogen plus progestin in postmenopausal women. N Engl J Med. (2009) 360:573-87. doi: 10.1056/NEJMoa0807684

9. Rossouw JE, Anderson GL, Prentice RL, LaCroix AZ, Kooperberg C, Stefanick ML, et al. Risks and benefits of estrogen plus progestin in healthy postmenopausal women: principal results From the Women's Health Initiative randomized controlled trial. JAMA. (2002) 288:32133. doi: 10.1001/jama.288.3.321

10. Palacios S, Mejias A. An update on drugs for the treatment of menopausal symptoms. Expert Opin Pharmacother. (2015) 16:2437-47. doi: 10.1517/14656566.2015.1085508

11. Stuenkel CA. Menopausal hormone therapy: current considerations. Endocrinol Metab Clin North Am. (2015) 44:56585. doi: 10.1016/j.ecl.2015.05.006

12. Pinkerton JV, Thomas S. Use of SERMs for treatment in postmenopausal women. J Steroid Biochem Mol Biol. (2014) 142:142-54. doi: 10.1016/j.jsbmb.2013.12.011

13. Barrett-Connor E, Mosca L, Collins P, Geiger MJ, Grady D, Kornitzer $\mathrm{M}$, et al. Effects of raloxifene on cardiovascular events and breast cancer in postmenopausal women. $N$ Engl J Med. (2006) 355:12537. doi: 10.1056/NEJMoa062462

14. Axell AM, MacLean HE, Plant DR, Harcourt LJ, Davis JA, Jimenez M, et al. Continuous testosterone administration prevents skeletal muscle atrophy and enhances resistance to fatigue in orchidectomized male mice. Am J Physiol Endocrinol Metab. (2006) 291:E506-16. doi: 10.1152/ajpendo. 00058.2006
Drafting of manuscript: PR and MK. Critical revision: SS, WL, and MK. All authors read and approved the final version of this manuscript.

\section{ACKNOWLEDGMENTS}

This study was supported by the German Research Foundation (DFG SE 1966/6-1, KO 4646/3-1). The authors are grateful to their colleagues R. Wigger, R. Castro-Machguth, and A. Witt for their technical support.

15. Bhasin S, Storer TW, Berman N, Callegari C, Clevenger B, Phillips J, et al. The effects of supraphysiologic doses of testosterone on muscle size and strength in normal men. $N$ Engl J Med. (1996) 335:17. doi: 10.1056/NEJM199607043350101

16. Sih R, Morley JE, Kaiser FE, Perry HM, 3rd, Patrick P, Ross C. Testosterone replacement in older hypogonadal men: a 12-month randomized controlled trial. J Clin Endocrinol Metab. (1997) 82:1661-7. doi: 10.1210/jcem.82.6.3988

17. Urban RJ, Bodenburg YH, Gilkison C, Foxworth J, Coggan AR, Wolfe RR, et al. Testosterone administration to elderly men increases skeletal muscle strength and protein synthesis. Am J Physiol. (1995) 269(5 Pt 1):E8206. doi: 10.1152/ajpendo.1995.269.5.E820

18. Elraiyah T, Sonbol MB, Wang Z, Khairalseed T, Asi N, Undavalli C, et al. Clinical review: the benefits and harms of systemic testosterone therapy in postmenopausal women with normal adrenal function: a systematic review and meta-analysis. J Clin Endocrinol Metab. (2014) 99:354350. doi: 10.1210/jc.2014-2262

19. Basaria S, Coviello AD, Travison TG, Storer TW, Farwell WR, Jette AM, et al. Adverse events associated with testosterone administration. $N$ Engl J Med. (2010) 363:109-22. doi: 10.1056/NEJMoa1000485

20. Girgis CM, Mokbel N, Digirolamo DJ. Therapies for musculoskeletal disease: can we treat two birds with one stone? Curr Osteoporos Rep. (2014) 12:14253. doi: 10.1007/s11914-014-0204-5

21. Almeida M, Laurent MR, Dubois V, Claessens F, O'Brien CA, Bouillon R, et al. Estrogens and androgens in skeletal physiology and pathophysiology. Physiol Rev. (2017) 97:135-87. doi: 10.1152/physrev.00033.2015

22. Bhasin S, Calof OM, Storer TW, Lee ML, Mazer NA, Jasuja R, et al. Drug insight: testosterone and selective androgen receptor modulators as anabolic therapies for chronic illness and aging. Nat Clin Pract Endocrinol Metab. (2006) 2:146-59. doi: 10.1038/ncpendmet0120

23. Narayanan R, Mohler ML, Bohl CE, Miller DD, Dalton JT. Selective androgen receptor modulators in preclinical and clinical development. Nucl Recept Signal. (2008) 6:e010. doi: 10.1621/nrs.06010

24. Dalton JT, Barnette KG, Bohl CE, Hancock ML, Rodriguez D, Dodson ST, et al. The selective androgen receptor modulator GTx-024 (enobosarm) improves lean body mass and physical function in healthy elderly men and postmenopausal women: results of a double-blind, placebocontrolled phase II trial. J Cachexia Sarcopenia Muscle. (2011) 2:15361. doi: 10.1007/s13539-011-0034-6

25. Dobs AS, Boccia RV, Croot CC, Gabrail NY, Dalton JT, Hancock ML, et al. Effects of enobosarm on muscle wasting and physical function in patients with cancer: a double-blind, randomised controlled phase 2 trial. Lancet Oncol. (2013) 14:335-45. doi: 10.1016/S1470-2045(13)70055-X

26. Crawford J, Prado CM, Johnston MA, Gralla RJ, Taylor RP, Hancock ML, et al. Study design and rationale for the phase 3 clinical development program of enobosarm, a selective androgen receptor modulator, for the prevention and treatment of muscle wasting in cancer patients (POWER trials). Curr Oncol Rep. (2016) 18:37. doi: 10.1007/s11912-016-0522-0

27. Basaria S, Collins L, Dillon EL, Orwoll K, Storer TW, Miciek R, et al. The safety, pharmacokinetics, and effects of LGD-4033, a novel nonsteroidal oral, selective androgen receptor modulator, in healthy young men. J Gerontol A Biol Sci Med Sci. (2013) 68:87-95. doi: 10.1093/gerona/gls078

28. Bhasin S. Selective androgen receptor modulators as function promoting therapies. J Frailty Aging. (2015) 4:121-2. doi: 10.14283/jfa.2015.65 
29. Tieland M, Trouwborst I, Clark BC. Skeletal muscle performance and ageing. J Cachexia Sarcopenia Muscle. (2018) 9:3-19. doi: 10.1002/jcsm.12238

30. Kalu DN. The ovariectomized rat model of postmenopausal bone loss. Bone Miner. (1991) 15:175-91. doi: 10.1016/0169-6009(91)90124-I

31. McCormick KM, Burns KL, Piccone CM, Gosselin LE, Brazeau GA. Effects of ovariectomy and estrogen on skeletal muscle function in growing rats. J Muscle Res Cell Motil. (2004) 25:21-7. doi: 10.1023/B:JURE.0000021398.78327.39

32. Hoffmann DB, Komrakova M, Pflug S, von Oertzen M, Saul D, Weiser L, et al. Evaluation of ostarine as a selective androgen receptor modulator in a rat model of postmenopausal osteoporosis. J Bone Miner Metab. (2019) 37:243-55. doi: 10.1007/s00774-018-0929-9

33. Komrakova M, Furtwangler J, Hoffmann DB, Lehmann W, Schilling AF, Sehmisch S. The selective androgen receptor modulator ostarine improves bone healing in ovariectomized rats. Calcif Tissue Int. (2020) 106:14757. doi: 10.1007/s00223-019-00613-1

34. Komrakova M, Rechholtz C, Pohlmann N, Lehmann W, Schilling AF, Wigger $\mathrm{R}$, et al. Effect of alendronate or 8-prenylnaringenin applied as a single therapy or in combination with vibration on muscle structure and bone healing in ovariectomized rats. Bone Rep. (2019) 11:100224. doi: 10.1016/j.bonr.2019.100224

35. Brancaccio P, Maffulli N, Limongelli FM. Creatine kinase monitoring in sport medicine. Br Med Bull. (2007) 81-82:209-30. doi: 10.1093/bmb/ldm014

36. Moline SW, Glenner GG. Ultrarapid tissue freezing in liquid nitrogen. $J$ Histochem Cytochem. (1964) 12:777-83. doi: 10.1177/12.10.777

37. Andersen P. Capillary density in skeletal muscle of man. Acta Physiol Scand. (1975) 95:203-5. doi: 10.1111/j.1748-1716.1975.tb10043.x

38. Komrakova M, Werner C, Wicke M, Nguyen BT, Sehmisch S, Tezval M, et al. Effect of daidzein, 4-methylbenzylidene camphor or estrogen on gastrocnemius muscle of osteoporotic rats undergoing tibia healing period. J Endocrinol. (2009) 201:253-62. doi: 10.1677/JOE-08-0521

39. Saul D, Geisberg LK, Gehle T, Hoffmann DB, Tezval M, Sehmisch $\mathrm{S}$, et al. Changes in musculoskeletal system and metabolism in osteoporotic rats treated with urocortin. Front Endocrinol. (2019) 10:400. doi: 10.3389/fendo.2019.00400

40. Meijer AE. Histochemical method for the demonstration of myosin adenosine triphosphatase in muscle tissues. Histochemie. (1970) 22:518. doi: $10.1007 / \mathrm{BF} 00310550$

41. Horak V. A successive histochemical staining for succinate dehydrogenase and "reversed" -ATPase in a single section for the skeletal muscle fibre typing. Histochemistry. (1983) 78:545-53. doi: 10.1007/BF00496207

42. Peter JB, Barnard RJ, Edgerton VR, Gillespie CA, Stempel KE. Metabolic profiles of three fiber types of skeletal muscle in guinea pigs and rabbits. Biochemistry. (1972) 11:2627-33. doi: 10.1021/bi00 764a013

43. Hoppeler H. Exercise-induced ultrastructural changes in skeletal muscle. Int $J$ Sports Med. (1986) 7:187-204. doi: 10.1055/s-2008-1025758

44. Saul D, Harlas B, Ahrabi A, Kosinsky RL, Hoffmann DB, Wassmann M, et al. Effect of strontium ranelate on the muscle and vertebrae of ovariectomized rats. Calcif Tissue Int. (2018) 102:705-19. doi: 10.1007/s00223-017-0374-0

45. Komrakova M, Krischek C, Wicke M, Sehmisch S, Tezval M, Rohrberg $\mathrm{M}$, et al. Influence of intermittent administration of parathyroid hormone on muscle tissue and bone healing in orchiectomized rats or controls. $J$ Endocrinol. (2011) 209:9-19. doi: 10.1530/JOE-10-0353

46. Faloona GR, Srere PA. Escherichia coli citrate synthase. Purification and the effect of potassium on some properties. Biochemistry. (1969) 8:4497503. doi: 10.1021/bi00839a041

47. Hatefi Y, Stiggall DL. Preparation and properties of NADH: cytochrome c oxidoreductase (complex I-III). Methods Enzymol. (1978) 53:5-10. doi: 10.1016/S0076-6879(78)53005-X

48. Murata Y, Robertson KM, Jones ME, Simpson ER. Effect of estrogen deficiency in the male: the ArKO mouse model. Mol Cell Endocrinol. (2002) 193:712. doi: 10.1016/S0303-7207(02)00090-4

49. Rochira V, Kara E, Carani C. The endocrine role of estrogens on human male skeleton. Int J Endocrinol. (2015) 2015:165215. doi: 10.1155/2015/165215

50. Butera PC. Estradiol and the control of food intake. Physiol Behav. (2010) 99:175-80. doi: 10.1016/j.physbeh.2009.06.010

51. Vajda EG, Hogue A, Griffiths KN, Chang WY, Burnett K, Chen Y, et al. Combination treatment with a selective androgen receptor modulator
$\mathrm{q}(\mathrm{SARM})$ and a bisphosphonate has additive effects in osteopenic female rats. J Bone Miner Res. (2009) 24:231-40. doi: 10.1359/jbmr.081007

52. Kearbey JD, Gao W, Narayanan R, Fisher SJ, Wu D, Miller DD, et al. Selective androgen receptor modulator (SARM) treatment prevents bone loss and reduces body fat in ovariectomized rats. Pharm Res. (2007) 24:32835. doi: 10.1007/s11095-006-9152-9

53. Komrakova M, Hoffmann DB, Nuehnen V, Stueber H, Wassmann M, Wicke $\mathrm{M}$, et al. The effect of vibration treatments combined with teriparatide or strontium ranelate on bone healing and muscle in ovariectomized rats. Calcif Tissue Int. (2016) 99:408-22. doi: 10.1007/s00223-016-0156-0

54. Fisher JS, Hasser EM, Brown M. Effects of ovariectomy and hindlimb unloading on skeletal muscle. J Appl Physiol. (1998) 85:1316-21. doi: 10.1152/jappl.1998.85.4.1316

55. Kobori M, Yamamuro T. Effects of gonadectomy and estrogen administration on rat skeletal muscle. Clin Orthop Relat Res. (1989) 243:306-11. doi: 10.1097/00003086-198906000-00045

56. Neto W, de W, Silva A, Ciena A, Souza R, Carbone P, et al. Testosterone is key to increase the muscle capillary density of old and trained rats. J Morphol Soc. (2019). 36:182-9. doi: 10.1055/s-0039-1692209

57. Yu JG, Bonnerud P, Eriksson A, Stal PS, Tegner Y, Malm C. Effects of long term supplementation of anabolic androgen steroids on human skeletal muscle. PLoS ONE. (2014) 9:e105330. doi: 10.1371/journal.pone.0105330

58. Tesch PA, Wright JE, Vogel JA, Daniels WL, Sharp DS, Sjodin B. The influence of muscle metabolic characteristics on physical performance. Eur J Appl Physiol Occup Physiol. (1985) 54:237-43. doi: 10.1007/BF00426139

59. Wiegand G, Remington SJ. Citrate synthase: structure, control, and mechanism. Annu Rev Biophys Biophys Chem. (1986) 15:97-117. doi: 10.1146/annurev.bb.15.060186.000525

60. Gillen JB, Martin BJ, MacInnis MJ, Skelly LE, Tarnopolsky MA, Gibala MJ. Twelve weeks of sprint interval training improves indices of cardiometabolic health similar to traditional endurance training despite a five-fold lower exercise volume and time commitment. PLOS ONE. (2016) 11:e0154075. doi: 10.1371/journal.pone.0154075

61. Larsen S, Nielsen J, Hansen CN, Nielsen LB, Wibrand F, Stride $\mathrm{N}$, et al. Biomarkers of mitochondrial content in skeletal muscle of healthy young human subjects. J Physiol. (2012) 590:334960. doi: 10.1113/jphysiol.2012.230185

62. Vigelso A, Andersen NB, Dela F. The relationship between skeletal muscle mitochondrial citrate synthase activity and whole body oxygen uptake adaptations in response to exercise training. Int J Physiol Pathophysiol Pharmacol. (2014) 6:84-101.

63. Phypers B, Pierce JMT. Lactate physiology in health and disease. Continuing Education in Anaesthesia. Crit Care Pain. (2006) 6:12832. doi: 10.1093/bjaceaccp/mkl018

64. Schmidt A, Kimmel DB, Bai C, Scafonas A, Rutledge S, Vogel RL, et al. Discovery of the selective androgen receptor modulator MK-0773 using a rational development strategy based on differential transcriptional requirements for androgenic anabolism versus reproductive physiology. J Biol Chem. (2010) 285:17054-64. doi: 10.1074/jbc.M109.099002

65. Furuya K, Yamamoto N, Ohyabu Y, Morikyu T, Ishige H, Albers $\mathrm{M}$, et al. Mechanism of the tissue-specific action of the selective androgen receptor modulator S-101479. Biol Pharm Bull. (2013) 36:44251. doi: 10.1248/bpb.b12-00885

66. Simitsidellis I, Esnal-Zuffiaure A, Kelepouri O, O'Flaherty E, Gibson DA, Saunders PTK. Selective androgen receptor modulators (SARMs) have specific impacts on the mouse uterus. J Endocrinol. (2019) 242:22739. doi: 10.1530/JOE-19-0153

Conflict of Interest: The authors declare that the research was conducted in the absence of any commercial or financial relationships that could be construed as a potential conflict of interest.

Copyright (๑ 2020 Roch, Henkies, Carstens, Krischek, Lehmann, Komrakova and Sehmisch. This is an open-access article distributed under the terms of the Creative Commons Attribution License (CC BY). The use, distribution or reproduction in other forums is permitted, provided the original author(s) and the copyright owner(s) are credited and that the original publication in this journal is cited, in accordance with accepted academic practice. No use, distribution or reproduction is permitted which does not comply with these terms. 